\title{
THE CHANGES IN SKIN TEMPERATURES OF PERIPARTURIENT SOWS
}

\author{
V. KOTRBÁČEK and H.-R. NAU \\ Department of Physiology, University of Veterinary Science, \\ 61242 Brno and Bereich Physiologie, \\ Sektion Tierproduktion und Veterinärmedizin, Humboldt-Universität, Berlin
}

Received fune 4, 1984

\begin{abstract}
Kotrbáček, V., Nau, H.-R.: The Changes in Skin Temperatures of Periparturient Sows. Acta vet. Brno, 54, 1985: 35-40.

In a breeding herd of 20 Large White sows skin temperature over the mammary gland was determined by means of an AGA 680 Thermovision System.

In the last days of pregnancy but particularly after parturition the skin over the mammary gland was the warmest area of body surface. On the first day of lactation temperatures of $39^{\circ} \mathrm{C}$ were found over limited skin areas covering the body of the mammary gland. Later during lactation period the recorded average skin temperatures were between 37 and $38^{\circ} \mathrm{C}$. Skin temperatures of the piglets huddling against their mother were very close to the temperature of her mammary gland which together with the litter formed one isothermal complex supporting the integrity of the mother-offspring biological unit.
\end{abstract}

Thermography, thermal environment, piglets, heat source.

Skin temperature especially in relation to heat loss from the body is an important physiological parameter. In pigs, its changes have been described in detail e.g. in context with changes in the thermal environment (Holub 1958; Lávička et al. 1960; Ly hs et al. 1969; McGinnis et al. 1981). Recently introduced measurement of skin temperatures over various parts of body surface by means of thermistor probes provides average temperature values, however, without an accurate distribution pattern and time dynamics of these changes. Therefore in order to obtain more precise data increasingly often the thermographic method has been employed (Clark et al. 1978; Clark and Stothers 1980; Kotrbáček and $\mathrm{Nau} 1983$ ). Its advantage lies not only in the possibility to determine the distribution of skin temperatures but also in the fact that there is no contact necessary with the measured object. Hence, in experimental animals the measurements may be carried out in their natural environment without disturbing them.

These advantages prompted us to employ thermography for measurement of skin temperature of the mammary gland in sows in the period before, during and after parturition. We felt that it was necessary to obtain information about the temperature pattern of this body area and its changes in the period when the sow is not only the source of nutrition but obviously also an important source of heat to her newborn offspring.

\section{Material and Methods}

The measurements were carried out in a farrowing house in which a breeding herd of 20 healthy White Large sows were kept in boxes $2 \times 3 \mathrm{~m}$ on straw bedding. First the thermal conditions of the house were defined by means of the electric dynamic katathermometer (EDK) as described by Cesnek and Novák (1971). The so-called cooling properties of the environment (CPE) were determined as previously described (Kotrbáček et al. 1979). The CPE was determined $13 \mathrm{~cm}$ above the floor of the central alley of the house, in boxes for sows and in nests for piglets that had been heated by electric infrared lamps $(250 \mathrm{~W})$. Simultaneously, the air temperature was measured at these sites by a mercury thermometer. 
In sows, skin temperature over the mammary gland was measured immediately before and during parturition, and at various intervals afterwards. An AGA 680 Thermovision System was employed recording the natural skin radiation in the infrared part of spectrum in form of a visible thermal picture. The results obtained by EDK measurements were evaluated by Student's t-test.

\section{Results}

The cooling properties of environment (CPE) measured in the central alley of the farrowing house were $383 \pm 9.9 \mathrm{~W} . \mathrm{m}^{-2}$. In boxes for sows, the CPE were significantly $(0.01<\mathrm{P}<0.02)$ lower amounting for $304 \pm 7.4 \mathrm{~W} . \mathrm{m}^{-2}$. As expected, they were further decreased under the infrared lamps to $201 \pm 8.6 \mathrm{~W} \cdot \mathrm{m}^{-2}(\mathrm{P}<0.01)$. The mean air temperature in the central alley was $13.8 \pm 0.74{ }^{\circ} \mathrm{C}$ and in boxes for sows it increased to $15.6 \pm 0.44^{\circ} \mathrm{C}(0.02<\mathrm{P}<0.05)$. The highest air temperature was found under the infrared lamps of $20.7 \pm 0.18^{\circ} \mathrm{C}$.

In gilts before pregnancy the highest skin temperature of $37^{\circ} \mathrm{C}$ was found at some sites in the center of the hind limb, behind the ear and on the shoulder blade (Fig. 1). This temperature was limited to only small skin areas. The isotherms depicting the temperature of $35.5^{\circ} \mathrm{C}$ extended to larger skin areas and occurred also on the lateral surface of the belly (Fig. 2). In sows immediately prior to parturition such warm area became that of the mammary gland basis (Fig. 3). The sow with her piglets a few hours after parturition is shown in Fig. 4. The light area between the piglets is their skin area of $39^{\circ} \mathrm{C}$. The isotherms depicting the skin temperature areas of $38.0^{\circ} \mathrm{C}$ (Fig. 5) occur at sites where the piglets were touching each other and on the mammary gland of the sow still as small spots. Skin surface of $37.5^{\circ} \mathrm{C}$ extended to larger areas of the mammary gland and body surface of the piglets (Fig. 6), and isotherms of $37^{\circ} \mathrm{C}$ delineated practically the entire mammary gland and the litter of piglets (Fig. 7).

The temperature of $39.0^{\circ} \mathrm{C}$ in a sow with one-day old piglets was visible only in the center of the litter and as two small spots in the hind part of the mammary gland (Fig. 8). The skin temperature by $1{ }^{\circ} \mathrm{C}$ lower, i.e. $38.0^{\circ} \mathrm{C}$ expanded to wider areas, and isotherms of $37.0^{\circ} \mathrm{C}$ delineated the mammary gland and the litter as a whole (Fig. 9 and 10).

High skin temperatures of the mammary gland in sows were also found in later periods, i.e. 23 days after parturition (Fig. 11), and 40 days thereafter (Fig. 12).

\section{Discussion}

The thermal picture of the skin in pigs may be described as a mosaic of areas with different temperatures that are in a dynamic relation to heat production of the body on the one hand and to thermal conditions of the environment on the other hand. An important role in heat loss regulation in piglets is that of the apical organs (Vrbenská and Holub 1961). Their contribution to maintaining the heat balance in pigs weighing ca $50 \mathrm{~kg}$ was studied by Lyhs et al. (1959). Distribution of skin temperatures as described by these authors was comparable to thermograms obtained in our non-pregnant gilts. However, in sows immediately before parturition and during lactation a different situation occurred. In all animals, the highest skin temperature was definitely that of the mammary gland area. In a number of sows it hovered at the level of their rectal temperature prior to parturition. Littledike et al. (1979) found in periparturient sows a rapid increase in peritoneal temperature reaching $40.3^{\circ} \mathrm{C}$ and remaining at this level throughout the second week after parturition. This high body 

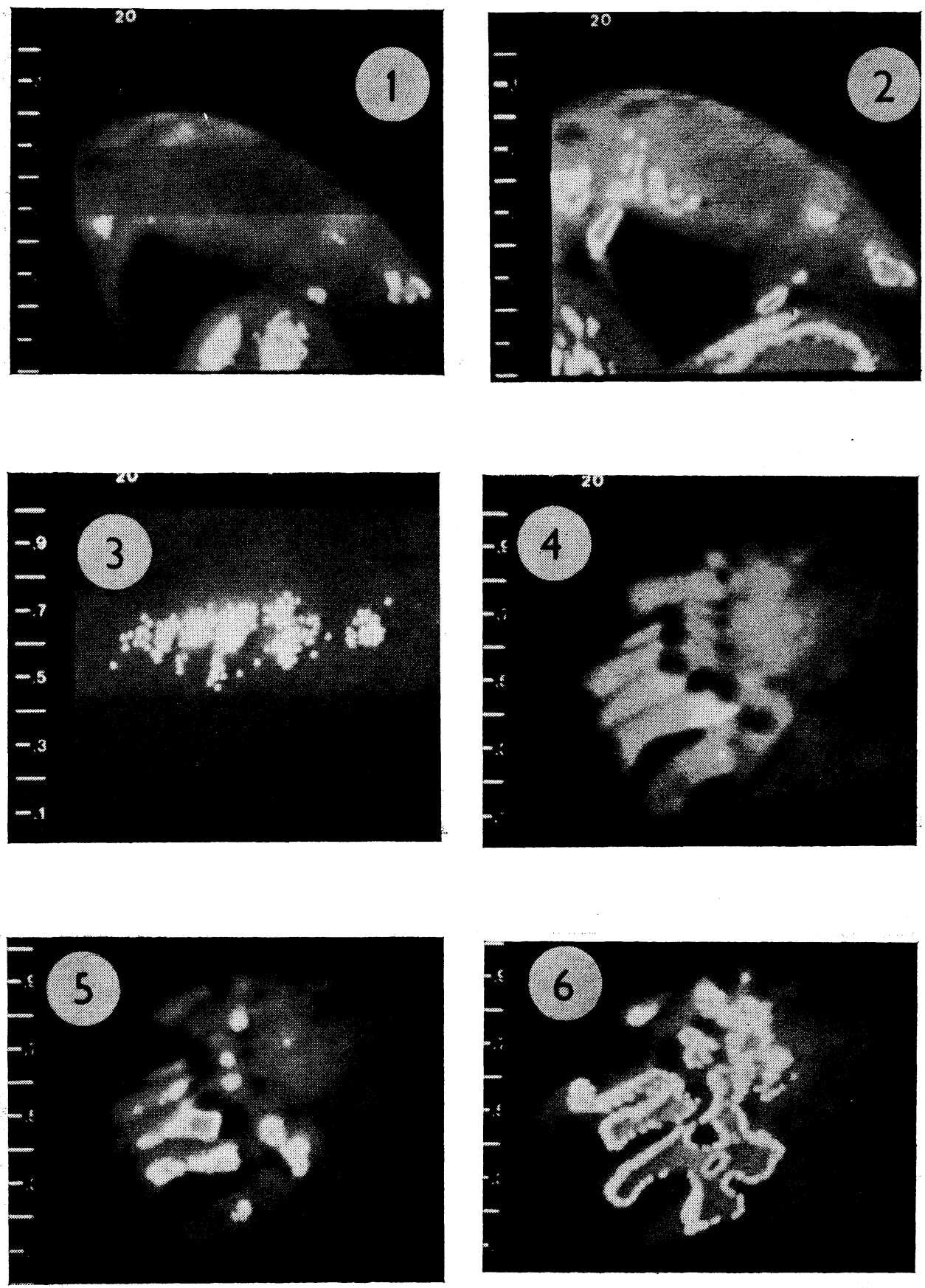

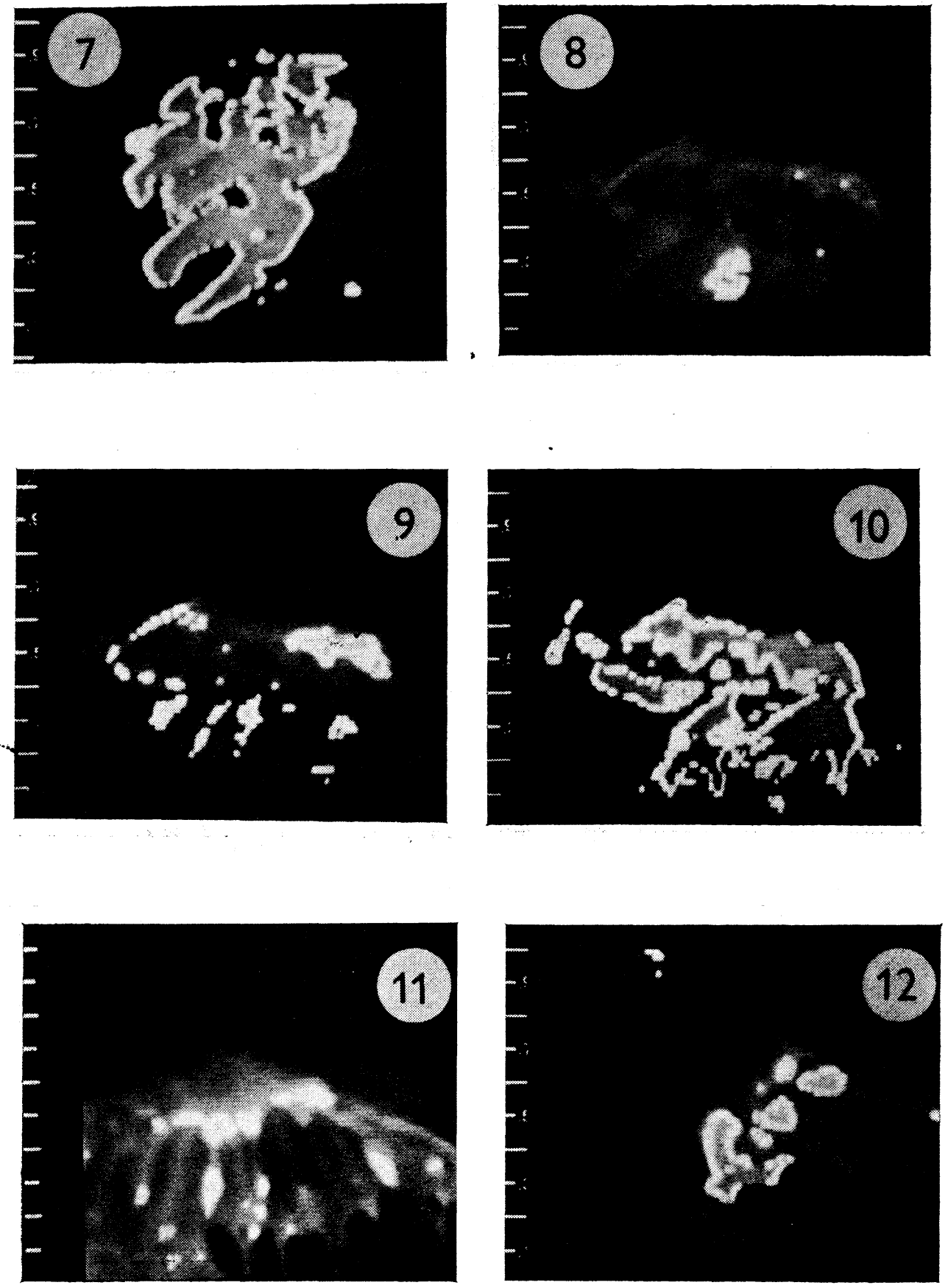
temperature is, no doubt, connected with the high metabolic rate due to lactation and obviously also due to difficulties in heat dissipation, particularly from some parts of the body surface. The mammary gland certainly may affect the heat dissipation from the body not only by its large surface but as shown in our Figures by its high skin temperature.

A more intriguing question was that of the mammary gland function as a heat source for piglets. In previous experiments we observed that the piglets heated in a metabolic chamber through a $38.0^{\circ} \mathrm{C}$ warm floor had the lowest heat production even if the cooling properties of the environment (CPE) were considerably high. The conductive heat transfer at this surface temperature of the floor was so efficient that even the behaviour of piglets changed substantially. They rapidly calmed and almost always fell asleep (Kotrbáček and Holub 1982). The mammary gland with its surface temperature of about $38^{\circ} \mathrm{C}$ may therefore considerably contribute to the thermal comfort and calming down of the piglets. Apart from suckling, it certainly is one of the reasons why the piglets look for their mother and spend much time huddled against her body. The beneficial effect of the mother upon maintaining their thermal balance was confirmed by the fact that the piglets would stay with their mother after suckling. In spite of a high CPE in the farrowing house their skin temperatures did not differ appreciably from that of the mammary gland surface of the sow. In many of our thermograms no distinction could be made between the mammary gland and the suckling litter. Such picture, however, was only obtained with the sow laying in so-called suckling position with her mammary gland exposed to the piglets. When the sow was laying in sternal position the piglets were mostly not on her. This phenomenon was also observed by Petherick (1982-83) who, moreover, found that with advancing age of piglets the sow would assume sternal recumbency ircreasingly often and the piglets would have to find another heat source.

In conclusion, the mammary gland of sows becomes the warmest part of the body in the periparturient period ard its surface temperature continues to remain high throughout the sucklirg period most probably due to lactation. The heat given off by mammary gland is, no doubt, of considerable importance for maintaining the thermal balance of the sow herself and her litter. The mammary gland of the sow and her litter thus form one isothermal complex supporting the coherence of the biological unit mother-offspring.

\section{Změny kožních teplot prasnic po porodu}

U kmenového stáda 20 prasnic plemene německého ušlechtilého byla pomocí termovizního systému AGA 680 zjištována teplota kủže mléčné žlázy.

$\mathrm{V}$ posledních drech březosti a zejména po porodu byl povrch mléčné žlázy prasnice nejteplejší kožní oblastí. V prvém dnu laktace jsme na omezených okrscích zjištovali teploty $39^{\circ} \mathrm{C}$. V dalším průběhu laktace se průměrné teploty povrchu mléčné žlázy pohybovaly od 37 do $38^{\circ} \mathrm{C}$. Teploty kủže selat sajících či odpočívajících u prasnice se těmto hodnotám přibližovaly. Mléčná žláza a selata tak vytvářela jeden izotermální komplex, podporující soudržnost biologické jednotky matka - mládata.

\section{Изменения температуры кожи свиноматок после опороса}

У основното стада 20 свиноматок немецкого породистого племени с помощью термовизуальной системы АГА 680 изучали температуру кожи молочной железы. 
В последние дни беременности, в особенности после опороса была поверхность молочной железы свиноматки самой теплой областью кожи. В первый день лактации на ограниченных участках была установлена температура $39{ }^{\circ} \mathrm{C}$. В последующий период лактации средняя температура на поверхности молочной железы достигала $37-38^{\circ} \mathrm{C}$. Температура кожи кормящихся или отдыхающих около свиноматки молочных поросят приближалась приведенным величинам. Молочная железа и поросята таким образом создавали единый изотермичеокий комплекс, способствующий сплоченности биологической единицы мать - молодняк.

\section{References}

CLARK, R. P. - CROSS, K. W. - GOFF, M. R. - MULLAN, B. J. - STOTHERS, J. K. WARNER, R. M.: Neonatal whole-body thermography. J. Physiol., 280, 1978: 2-3P.

CLARK, R. P. - STOTHERS, J. K.: Neonatal skin temperature distributicn using infra-red colour thermography. J. Physiol., 302, 1980: 323-333.

ČESNEK, J. - NOVÁK, L.: Electrical kathermometer, its construction and some examples of its use in physiological experiment. Physiol. bohemoslov. 20, 1971: 57.

HOLUB, A.: Vývoj teploty kưže u selat. Cs. fysiol., 7, 1958: 350-351.

KOTRBÁČEK, V. - HOLUB, A. - ČESNEK, J.: Elektrický dynamický katatermometr a tepelné podmínky v doupatech pro selata. Ved. Med., Praha, 24, 1979: 449-454.

KOTRBÁČEK, V. - HOLUB, A.: Věkové změny energetického metabolismu selat v různém, komplexně definovaném tepelném prostředí. Čs. fysiol., 31, 1982: 464.

KOTRBÁCEK, V. - NAU, H. R.: Termografická analýza kožních teplot 'prasnic po porodu. Čs. fysiol., In Press.

LÁVIČKA, M. - NĚMEČEK, L. - HOLUB, A.: Vývoj teploty kůže u selat. Sb. Vet. Med., 5 (33), 1960: 109-118.

LYHS, L. - NICHELMANN, M. - STEINHARDT, M.: Hauttemperatur des Schweines bei verschiedener Umgebungstemperatur. Mh. Vet. Med., 24, 1969: 494-496.

LITTLEDIKE, E. T. - WITZEL, D. A. - RILEY, J. L.: Body temperature changes in sows during the periparturient period. Labor. Anim. Sci., 29, 1979: 621-624.

McGINNIS, R. M. - MARPLE, D. N. - GANJAN, V. K. - PRINCE, J. J. - PRITCHETT, J. F.: The effect of floor temperature, supplemental heat and drying at birth on neonatal swine. J. Anim. Sci., 53, 1981: 1424-1431.

PETHERICK, J. C.: A note on nursing termination and resting behaviour of suckling piglets. Appl. Anim. Ethol., 9, 1982-83: 359-365.

VRBENSKÁ, A. - HOLUB, A.: Růst boltců a vývoj termoregulace u selat. Vet. čas., 10, 1961: $11-19$. 